\title{
Analisis Semiotika Representasi Pria Metroseksual dalam Video Musik Seventeen "Thanks"
}

\author{
Grace Harpono, H.H Daniel Tamburian \\ graceharpono.915170132@stu.untar.ac.id,danielt@fikom.untar.ac.id
}

Fakultas Ilmu Komunikasi Universitas Tarimanagara

\begin{abstract}
Metrosexual men are men who take care of themselves and care about their appearance, at this time this is a natural thing and there are many beauty products specifically for men to maintain their appearance. At this time, the writer examines this through music video, with the aim of seeing how the metrosexual male representations that occur in the Seventeen music video entitled 'Thank you'. To be able to do this analysis, the writer conducted research by analyzing the clips in the music video, therefore in this study the writer chose to use qualitative research methods. This research technique uses Roland Barthes' semiotic analysis theory which sees signs as denotations and connotations. With data techniques using observation techniques. The observation technique referred to by the author is to make observations made by the author of the Seventeen music video entitled "Thank you". The author watches in detail to capture events or signs related to the topic analysis. From the observations made by the author, the narrative of events and clear scene snippets of the representation of metrosexual men as seen from the clothes, make-up, accessories, and hair used in the music video are supported by gender theory derived from Roland Barthes' semiotic analysis. the research conducted gets credible results from the authors.
\end{abstract}

Keywords: metrosexual, music video, representation, semiotics

\begin{abstract}
Abstrak
Pria metroseksual adalah pria yang merawat diri dan peduli dengan penampilannya. Saat ini hal tersebut merupakan hal yang wajar dan sudah banyak produk kecantikan yang dikhususkan untuk pria untuk menjaga penampilan mereka. Penulis meneliti hal tersebut melalui video musik, dengan tujuan untuk mengetahui bagaimana representasi pria metroseksual di dalam video musik Seventeen yang berjudul 'Thanks'. Untuk dapat melakukan analisis tersebut penulis melakukan penelitian dengan menganalisa cuplikancuplikan yang ada di dalam video musik terebut. Penulis menggunakan metode penelitian kuaitatif. Teknik penelitian ini menggunakan teori analisis semiotika Roland Barthes yang melihat tanda sebagai denotasi dan konotasi. Dengan teknik pengumpulan data dengan menggunakan teknik observasi. Teknik observasi yang dimaksud dengan penulis adalah dengan melakukan kegiatan pengamatan yang dilakukan penulis terhadap video musik Seventeen yang berjudul "Thanks". Penulis menyaksikan secara detail untuk menangkap peristiwa atau tanda yang terkait dengan topik analisis. Dari hasil pengamatan yang penulis lakukan, narasi peristiwa dan cuplikan adegan memperlihatkan jelas mengenai unsur representasi pria metroseksual yang terlihat dari pakaian, riasan, aksesoris, dan tata rambut yang digunakan dalam video musik tersebut. Penelitian ini didukung kajian tentang gender yang dikaitkan dengan karakteristik dari analisis semiotika Roland Barthes.
\end{abstract}

Keywords: metroseksual, representasi, semiotika, video musik 
Grace Harpono, H.H Daniel Tamburian: Analisis Semiotika Representasi Pria Metroseksual dalam Video Musik Seventeen "Thanks"

\section{Pendahuluan}

Gaya hidup pria dari waktu ke waktu dapat dilihat atau direpresentasikan melalui cara berpakaian, berdandan dan menata diri, hal tersebut mulai membentuk dan merepresentasikan pria yang pada saat ini dikenal dengan istilah pria metrosekual. Perkembangan zaman yang membuat adanya perubahan mulai menciptakan kebutuhan baru bagi kaum pria hal tersebut mulai membentuk adanya konsep pria metroseksual.

Perkembangan dunia kecantikan membuat banyak beredar di pasaran produk kecantikan atau perawatan kulit yang di buat khusus untuk pria, atau menggunakan pria sebagai model dari produk kecantikan tersebut. Hal ini menggambarkan bahwa konsep pria metroseksual banyak di jumpai di dalam masyarakat dan bukan lah hal yang aneh unutk dilihat. Salah satu contoh produk kecantikan yang menggunakan pria sebagai model dari produk tersebut adalah produk The Saem yang menjadikan boy group Seventeen sebagai Brand Ambassador.

Secara tidak disadari apa yang kita lihat di dalam media massa yaitu melalui Televisi, Film, Video musik dan yang ada Internet banyak yang menampilkan pria yang berkonsep sebagai pria metroseksual. Hal tersebut membuat kita seolah terbiasa melihat pria yang terlihat berpakaian rapih, bersih, dan berpenampilan menarik. Salah satu nya adalah melalui media video musik yang sangatlah berhubungan dengan konsep fashion dan dapat dilihat dari cara pengemasan melalui busana yang dikenakan oleh artis.

Dalam penelitian ini penulis memilih menggunakan teori analisis semiotika Roland Barthes dengan metode pendekatan kualitatif deskripsitf. Dalam Teori Smeiotika Roland Barthes terdapat signifier yang adalah penanda dan signified sebagai pertanda. Kedua hal tersebut dikembangkan menjadi teori dengan menggunakan dua sistem signifikasi yaitu makna denotasi dan makna konotasi. Makna denotasi adalah makna yang bersifat deskriptif dan tertutup dan secara virtual merupakan makna yang dianut oleh setiap angota didalam suatu kebudayaan. Sedangkan untuk makna denotasi merupakan makna yang dijabarkan secara detail dan merupakan makna yang disepakati secara bersama serta merujuk pada realitas sosial.

Aspek terbentuknya makna konotasi adalah melalui aspek kultural yang mendalam seperti keyakinan, ideologi, dan struktur sosial di dalam suatu masyarakat atau kebudayaan (Sobur, 2017:145). Makna konotasi bersifat terbuka terhadap penafsiran-penafsiran baru. Adanya relasi antara penanda dengan pertanda sangatlah penting untuk terbentuknya suatu tanda yang direlasikan dan dikembangkan oleh pengguna tanda. Hubungan antara keduanya pun bersifat arbitrer sehingga dalam makna denotasi tersebut menghasilkan makna yang eksplisit dan merupakan sistem signifikasi pertama. Sedangkan makna konotasi menghasilkan makna yang implisit dan merupakan sistem siginifikasi kedua (Vera, 2014:27).

Penyebaran komunikasi massa adalah dengan menggunakan media digital dan elektronik yang dana diakses dengan mudah pada saat ini. Komunikasi massa merupakan hasil komunikasi yang tercipta oleh hasil dari teknologi yang bersifat modern dan terdiri dari tiga jenis mulai dari media cetak, media elektronik dan media online. Komunkasi masssa merupakan sarana yang dapat menyampaikan pesan dan alat penghubung komunikator dan komunikan (Mulyana, 2010 :80-84). Komunikasi massa merupakan pesan yang disampaikan oleh pemberi pesan melalui media massa 
yang tijukan kepada penerima pesan dengan jumlah yang besar yang bersifat heterogen.

Video musik merupakan alat yang digunakan untuk menyampaikan pesan kepada masyarakat luas dengan tujuan untuk mempromosikan lagu dan memperkuat pesan yang terkandung di dalam video musik tersebut. Melalui video musik dapat dijadikan sebagai sarana penyampaian pesan yang bersifat persuasif dan dapat menyampaikan dan mrepresentasikan makna atau pesan, seperti pada video musik Seventeen yang berjudul 'Thanks' yang ingin di teliti oleh penulis mengenai representasi pria metroseksual yang di tampilkan melaui gaya berbusana, adegan, tatanan rambut dan make up yang digunakan dalam video musik tersebut.

Gaya hidup pria dari waktu ke waktu membentuk adanya kebutuhan baru sehingga para pria metroseksual akan melakukan hal-hal yang dapat menunjang penampilan nya. Akibat dari keinginan tersebut pria metroseksual mulai melakukan perawatan mempercantik diri. Hal tersebut merupakan hal yang lazim pada saat ini ketika melihat banyak pria yang menggunakan jasa perawatan yang biasa digunakan oleh wanita seperti jasa salon kecantikan untuk menata rambut, penggunaan make up dan skincare kecantikan wajah dan tubuh untuk menunjang penampilan mereka dan untuk keinginan untuk selalu mengikuti trend yang sedang berlangsung (Khoo dan Karan, 2007). Berawal dari keinginan untuk mengikuti trend tersebut pria metroseksual cenderung mempunyai perhatian lebih terhadap tokoh atau selebriti tertentu. Dengan melihat selebriti tertentu atau yang disukai cenderung dijadikan sebgai patokan sebgai contoh dalam berpenampilan yang menarik dan mengikuti perkembangan (Petova, 2012).

Penelitian ini mengangkat tentang pria metroseksual dan ingin melihat bagaimana representasi pria metroseksual dalam video musik Seventeen "Thanks"”. Adapun tujuan penelitian ini adalah untuk mengetahui bagaimana penggambaran pria metroseksual dalam video musik Seventeen "Thanks".

\section{Metode Penelitian}

Dalam penelitian ini penulis menggunakan metode penelitian kualitatif yang meneliti fenomena yang terjadi dengan dengan menggunakan teori alamiah dan data atau metode yang tersedia di sekitar dan dijabarkan dalam bentuk data yang bersifat deskriptif (Anggito, Albi \& Setiawan, 2018:7). Penelitian kualitatif adalah tradisi tertentu dalam $1 \mathrm{mu}$ pengetahuan sosial yang secara fundamental bergantung dari pengamatan pada manusia baik dalam kawasannya maupun dalam peristilahannya Kirk \& Miller (1986).

Metode penelitian ini merupakan cara ilmiah dengan tujuan untuk mendapatkan data dengan kegunaan tertentu digunakan untuk meneliti tanda-tanda bagaiman pria metroseksual dalam video musik tersebut dan untuk mendapatkan data melalui penelitian ini, selain itu penelitian kualitatif juga dapat menghasilkan data deskriptif berupa kata - kata dan kalimat untuk penggambaran dan penjelasan mengenai peristiwa yang sedang sedang di teliti.

Metode pengumpulan data yang digunakan oleh penulis adalah dengan menggunakan dua cara yaitu: pertama, melalui data primer yang akan berasal dari hasil observasi seacara langsung oleh penulis terhadap setiap adegan-adegan yang terkandung di dalam video musik tersebut; kedua, melalui data sekunder yang mencari sumber memalui buku, jurnal, sumber online serta studi kepustakaan lainnya. 
Penelitian ini dilakukan dengan teknik analisis data yaitu dengan menyusun dan menjabarkan data yang telah diperoleh dari hasil wawancara atau obervasi dan membagi data sesuai dengan kategori nya masing-masing dan memilih mana hal yang penting untuk dipelajari agar lebih mudah di pahami (Sugiyono 2012: 89). Teknik keabsahan data penelitian ini adalah dengan menggunakan triangulasi sumber mencari data dan menggali informasi serta kebenaran hasil observasi dari video musik tersebut.

\section{Hasil Temuan Dan Diskusi}

Seperti yang sudah dijelaskan pada melalui teori sebelumnya untuk mengetahui bagaimana representasi pria metroseksual terjadi di dalam video musik Seventeen tersebut adalah dengan melihat makna denotasi dan makna konotasi yang terkandung dalam video musik tersebut. Untuk menjabarkan pesan-pesan yang terkandung dalam video musik Seventeen yang berjudul "Thanks", dengan membahas satu per satu adegan atau cuplikan dari video musik tersebut agar dapat melihat bagaimana representasi tersebut terjadi. Video musik Seventeen yang berjudul Thanks merupakan lagu utama dari album Seventeen yang berjudul "Teen Age" diunggah pada tanggal 5 Februari 2018 pada akun Youtube resmi Seventeen saat ini sudah ditonton lebih dari 51 juta penonton.

Gambar 1. Akun Youtube Seventeen

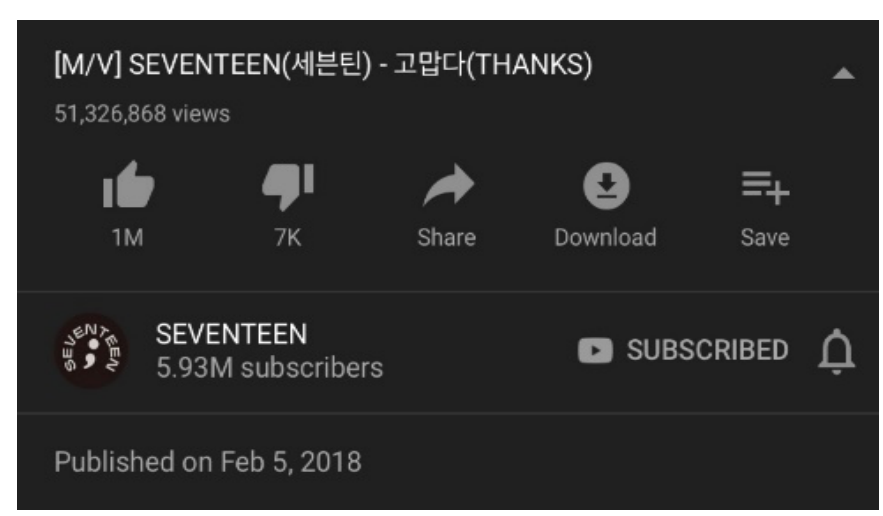

Sumber: Akun Youtube Resmi Seventeen

Melalui adegan yang ingin disampaikan oleh Seventeen tersebut penulis ingin menjabarkan beberapa adegan yang terdapat representasi pria metroseksual yang dilihat melalui persiapan mereka untuk naik ke atas panggung. Menjadi seorang Kpop star menuntut Seventeen untuk meperhatikan penampilan mereka. Oleh karena itu, dalam beberapa video musik mereka terdapat beberapa hal yang memperlihatkan diri seorang pria metroseksual. Karena pada dasarnya pria metroseksual adalah pria yang sangat mempedulikan penampilannya dan selalu mengikuti tren pakaian yang ada, selain itu juga mereka menggunakan perawatan wajah dan make-up untuk menunjang penampilan mereka. 
Gambar 2. Cuplikan Video musik Seventeen

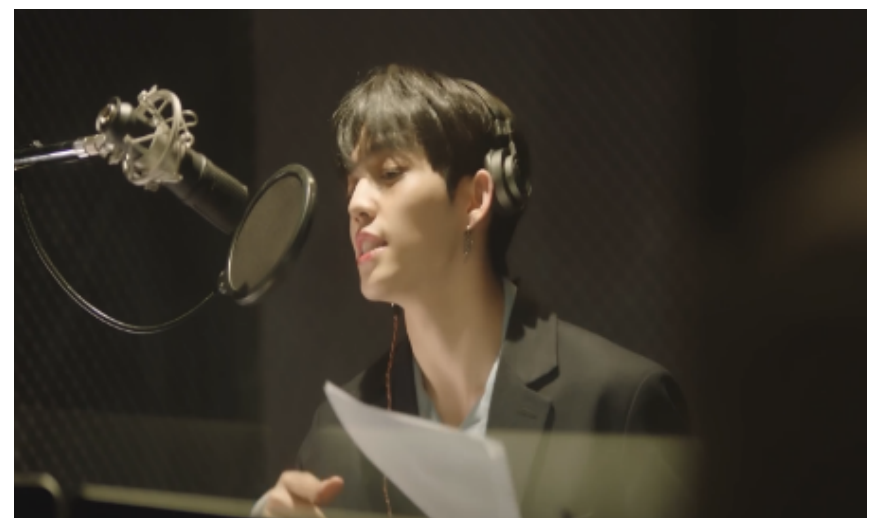

Sumber: Akun Youtube Resmi Seventeen

Makna Denotasi: Seorang pria yang bernama S.coups sedang berada di dalam ruang rekaman dan sedang melakukan rekaman dengan memegang kertas lirik lagu di tangannya.

Makna Konotasi: Penampilan S.coups yang rapi dengan menggunakan setelan jas berwarna hitam dengan kemeja berwarna biru. Pakaian dapat dijadikan atau sebagai alat komunikasi secara tidak langsung. Penggunaan pakaian dalam kehidupan sehari-hari dapat dijadikan fungsi sarana komunikasi baik dalam keadaan formal maupun informal (Barnard, 2011). Hal tersebut memperlihatkan bagaimana dia menjaga penampilannya bahkan saat sedang melakukan rekaman. Jika dilihat dalam Gambar 2, S.coups juga menggunakan anting menggantung salah satu tanda sebagai pria metroseksual yang juga dapat menjadi penanda pria metrosksual.

Gambar 3. Cuplikan Video musik Seventeen

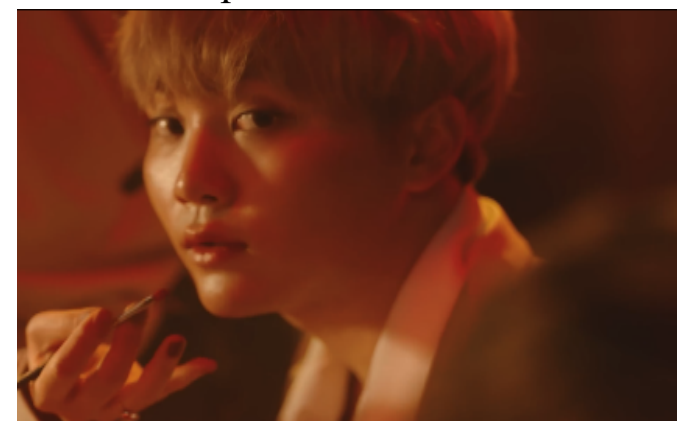

Sumber: Akun Youtube Resmi Seventeen

Makna Denotasi: Dalam Gambar 3, terlihat salah satu anggota yang bernama Seungkwan sedang melihat ke arah kamera. Dalam gambar tersebut juga terlihat bahwa Seungkwan sebuah tangan yang sedang merias wajahnya.

Makna Konotasi: Dalam Gambar 3, terlihat dengan jelas bagaimana penggambaran pria metroseksual Seungkwan yang didandani oleh seorang make-up artis profesional. Dalam upaya untuk mengunjang penampilan dan keinginan utnutk merawat diri agar tampil lebih baik, pria metroseksual menggunakan perawatan yang umumnya digunakan oleh wanita seperti jasa kecantikan seperti salon kacantikan untuk menata wajah, rambut, kulit dan bagian tubuh lainnya (Khoo dan Karan, 2007). Make-up adalah hal yang penting dan dapat menunjang penampilan seorang K-pop star saat dia berada di atas panggung. Seperti yang terlihat pada gambar 
Grace Harpono, H.H Daniel Tamburian: Analisis Semiotika Representasi Pria Metroseksual dalam Video Musik Seventeen "Thanks"

bukan hanya dari make-up saja namun melihat dari warna rambut Seungkwan yang diwarnai dengan warna yang terang juga salah satu tanda pria metroseksual.

Gambar 4. Cuplikan Video musik Seventeen

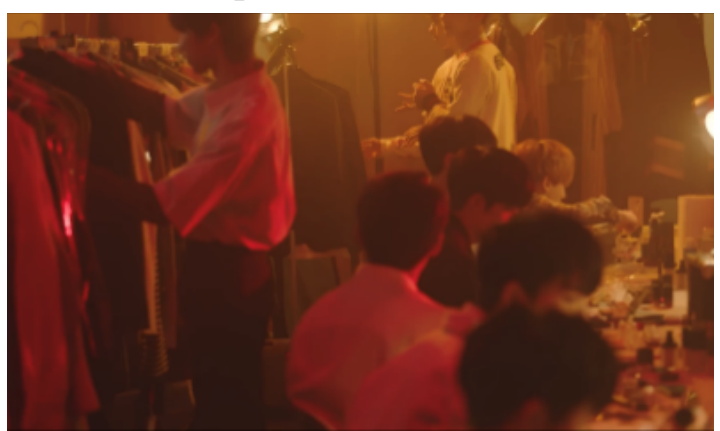

Sumber: Akun Youtube Resmi Seventeen

Makna Denotasi: dalam Gambar 4 tersebut terlihat anggota Seventeen yang duduk berbaris dan berada di dalam ruangan yang terdapat alat riasan serta ada beberapa anggota yang sedang berdiri melihat baju-baju yang di dalam ruangan tersebut.

Makna Konotasi: melalui gambar tersebut dapat terlihat bahwa keberadaan Seventeen di dalam ruangan tersebut dengan tujuan menunjang penampilan mereka. Di dalam ruangan yang berisi dengan riasan beserta dengan pakaian tersebut menadakan bahwa mereka sedang bersiap untuk naik ke atas panggung dan melakukan performance. Wacana media merepresentasikan sosok pria metroseksual adalah pria yang direpresentasikan sebagai sosok pria yang suka berdandan, merawat tubuh serta ingin selalu berpenampilan menarik dan mengikuti perkembangan trend (Beynon, dalam Dermatoto, 2010:8).

\section{Gambar 5. Cuplikan Video musik Seventeen}

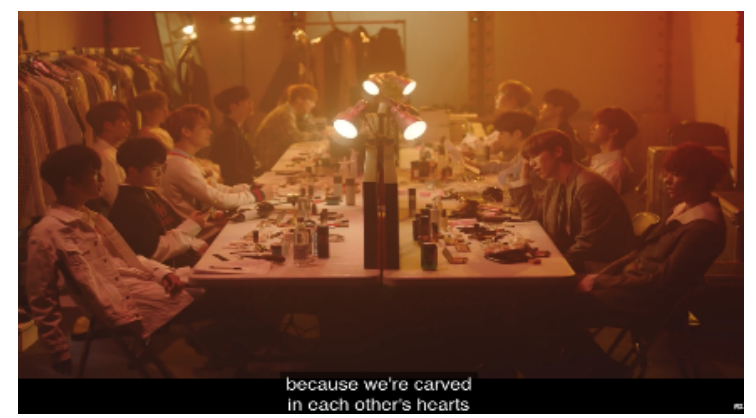

Sumber: Akun Youtube Seventeen

Makna Denotasi: gambar 5 adalah gambar yang sama dengan yang sebelumnya hanya saja terdapat perbedaan di dalam tersebut adalah teks yang bertuliskan "because we're craved in each other hearts".

Makna Konotasi: dalam Gambar 5 tersebut terdapat tulisan lirik lagu dari gambar sebelumnya yang bertuliskan "because we're craved in each other hearts". Yang artinya adalah "karena hati kita saling terukir" merupakan pesan yang ingin di sampaikan Seventeen kepada para penggemarnya adalah mereka akan terus memberikan yang terbaik sebagai satu kesautauan team yang saling melengkapi satu sama lain. Dan walaupun penampilan mereka yang begitu megah di atas panggung Seveneteen ingin mengatakan bahwa mereka adalah orang yang sama seperti pria 
biasa pada umumnya. Seventeen selalu berusaha memberikan yang terbaik dan penggemar mereka adalah hal yang terpenting dan akan selalu ada di dalam hati mereka.

Pria metroseksual yang menganggungkan fashion adalah tipe pria maskulin yang peduli dengan gaya hidup yang teratur, menyukai detail, dan cenderung perfectsionist. Selain itu sosok metroseksual dalam wacana media direpresentasikan dengan sosok pria yang berdandan, merawat tubuh, dan peduli penampilan serta berpakaian trendi (Beynon, dalam Dermatoto, 2010:8).

Pria metroseksual adalah pria yang merawat diri dan selalu berpenampilan menarik. Pada saat ini banyak pria yang tertarik dalam perkembangan dunia fashion yang mengahdirkan terobosan baju-baju yang lebih kompleks dan desain yang beragam jika dibandingkan dengan sebelumnya. menurut penulis hal tersebut adalah hal yang tidak asing di tengah perkembangan zaman pada saat ini, terlebih mengingat pekerjaaan mereka sebagai public figure yang mengharuskan mereka untuk berpenampilan menarik. Seventeen ingin menyampaikan melalui lagu ini adalah bagaimana persiapan dan perjuangan mereka dalam mempersembahkan yang terbaik bagi para penggemar yang selalu mendukung mereka dalam keadaan apapun, baik dari segi karya dan juga penapilam mereka

\section{Simpulan}

Sesuai dengan tujuan utama pembuatan penelitian ini adalah untuk mengetahu bagaimana representasi pria metroseksual terjadi di dalam video musik Seventeen yang berjudul "Thanks". Setelah dilakukan penelitian melalui analisis dan melakukan pengamatan terhadap cuplikan yang ada di dalam video musik tersebut penulis menarik kesimpulan sebagai berikut:

a. Dalam video musik Seventeen tersebut, dalam beberapa cuplikan mengandung representasi pria metroseksual yang dilihat dari riasan wajah, aksesoris yang digunakan, pakian, serta tatanan rambut.

b. Penelitian ini melihat bagaimana kehidupan masa kini di mana banyak pria ibukota mengikuti perkembangan zaman dan merawat diri mereka untuk terlihat lebih menarik.

c. Melalui penelitian ini penulis tidak hanya dapat meneliti gambar dan representasi pria metroseksual namun penulis juuga dapat memahami cara penyampaian pesan dengan memahami gambar dan lirik yang ada di dalam video musik tersebut.

\section{Ucapan Terima Kasih}

Penulis ingin berterima kasih kepada orang-orang yang membantu penulis dalam penelitian ini, khususnya kepada Fakultas Ilmu Komunikasi Universitas Tarumanagara.

\section{Daftar Pustaka}

Anggito, Albi \& Johan Setiawan. (2018). Metodologi penelitian kualitatif. Sukabumi: CV. Jejak.

Barnard, Laura K., Curry, John F. (2011). Self compassion: conceptualizations, correlates, \& interventions. American Psychological Association. 
Grace Harpono, H.H Daniel Tamburian: Analisis Semiotika Representasi Pria Metroseksual dalam Video Musik Seventeen "Thanks"

DA Burns, B Stephen, Cox Neil, G Christopher. (2010). Rook's textbook of dermatology. 8th edition. United Kingdom: Wiley-Blackwell Publishing.

Khoo, M., \& Karan, K. (2007). Macho or metroseksual: the branding of masculinity in FHM magazines in Singapura. Journal intercultural communication studies XVI:1.

Kirk, J dan Miller, M. L. (1986). Reliability and validity in qualitative research. Beverly Hills: Sage Publications.

Mulyana, D. (2010). Ilmu komunikasi suatu pengantar. (Cetakan Ke-9). Bandung: Rosdakarya.

Petova, S.S. (2012). Perilaku konsumtif terhadap fashion pada pria metroseksual yang berpenghasilan pas-pasan. Skripsi (tidak diterbitkan). Jakarta : Universitas Gunadarma.

Sobur, Alex. (2017). Semiotika komunikasi. Bandung: PT Remaja Rosdakarya.

Sugiyono. (2012). Metode penelitian kuantitatif kualitatif dan R\&D. Bandung: Alfabeta.

Vera, Nawiroh. (2014). Semiotika dalam riset komunikasi. Bogor: Penerbit Ghalia Indonesia. 